\title{
Research on Government-Industries-Universities-Research Collaborative Innovation Mechanism and Pattern of the Local Applied Undergraduate Institute
}

\author{
Yunbao Xu \\ College of Management \\ Hunan Institute of Engineering \\ Xiangtan, China \\ xyb@hnie.edu.cn
}

\author{
Huimin Chen \\ College of Economics \\ Hunan Institute of Engineering \\ Xiangtan, China \\ chm@hnie.edu.cn
}

\begin{abstract}
The quality of personnel training in the local applied undergraduate institute does not deserve guarantee because of all sorts of constraint factors such as the students' quality, teachers' quality and development orientation etc. It's a difficulty and chance for local applied undergraduate institute that they train the necessity personnel fit for society development in the shifting condition of economy and society. Accordingly, the collaborative innovation mechanisms of government, industries(or firms) and colleges(research institutes) are researched through the important aspects including interest relation and driving, knowledge increment, demand driving, achievements attracting and the government promoting firstly. Secondly, the collaborative innovation patterns of government, industries (or firms) and universities (research institutes) are analyzed from design platform of the combination of collaborative innovation, industrial clusterdiscipline construction and technical alliance. The governmentindustries-universities-research collaborative innovation mechanism can clear personnel training objectives and model and form an unique professional orientation and training model for the needs of the community. The Innovation of this paper is to blend into the combination of the role of government common in collaborative innovation, government plays a greater role in industries-universities-research. It's a developing tendency and a kind of progress for the local applied undergraduate institute from the perspective of talent cultivation. The local applied undergraduate institute can help to solve the local economy and science and technology problems, he is the important person of the realization of technology transfer and the transformation of achievements.
\end{abstract}

Keywords-government-industries-universitiesresearch;collaborative innovation;mechanism and pattern; local applied undergraduate institute

\section{INTRODUCTION}

Local applied undergraduate institute refers to the general undergraduate college which focuses on building a collaborative developing applied talents training mechanism with regional economic and social, it falls in between the university and the college or the senior high vocational school, building by the province and the city together, it has some decision-making power. A considerable part of the undergraduate institutes are upgraded from the colleges or the senior high vocational schools. Because of its efforts on ascending and the process of the rapid expansion: Lack of school funding, insufficient faculty, majors in blind, management experiences lacking, cause to the actual lower employment rate. That's the common problems existing in the local applied undergraduate institute. Domestic universities should think how to clear personnel training objectives and model and form an unique professional orientation and training model for the needs of the community.

Government-industries-universities-research

collaborative innovation can promote resources of science and technology and education enjoyment, promote innovation about organization management mode of local applied undergraduate institute, promotes combination of government-industries-universities-research. Local applied undergraduate institute is an important training base highlevel innovative talents, is one of the innovation main on application research, it can solve the local economy and science and technology problems, he is the important person of the realization of technology transfer and the transformation of achievements. At present situation, government-industries-universities-research collaborative innovation mechanism isn't still formed because of the benefit driving. To realize the high level and the high starting point innovation, we should carry on the innovation in a sound external demand drive mechanism dominated by the local government.

\section{A REVIEW OF THE LITERATURE}

Chinese scholars discuss the principle of governmentindustries-universities-research mainly in two aspects: the talents training education and innovation.

\section{A. Cooperative Research of Government-Industries- Universities-Research on Personnel Training}

Nelson \& Winter(1982)[1], Dosi et a1.(1988)[2] and Leydesdorff \& Besselaar(1994)[3] points out that "demand pull" and "technology push" linear innovation model is replaced by evolution model based on the interdisciplinary, organization (public and private) and the national boundary cooperation under the network development, Freeman(1987)[4] and Nelson(1993)[5] talked about that the national innovation system were broken by the European Union and other regional or cross-border governmentindustries-universities innovation system (defect which is showing the theory of national innovation systems and 
insufficient), or to be supplemented. The United Nations, the world bank, the European Union and other international or multinational project in the government-industriesuniversities partnership in order to achieve the purpose of promoting the development of economy, as a new mode of production in the hinge of government-industriesuniversities of the interface.

Liu Yunfei, Wu Xuesong(2008)[6] thought that it's an important practice of running a school and school characteristics to promote the cooperation of education and training applied talents for the local applied undergraduate institute, so we must profound understand the scientific connotation of cooperative education on industriesuniversities-research, wide reference mode of the cooperative education on industries-universities-research in western developed countries, innovation the cooperative education system on industries-universities-research, innovation talent training mode and operation mechanism, and talent cultivation system; Zhou Huali, Xiao Zhangke, Luo Yao(2010)[7] discussed the industries-universitiesresearch cooperation way on "the entire enterprise intervention" and "campus virtual enterprises" and "cooperative school administration" and "strategic cooperation" and etec. on the basis of existing foundation of Beijing Union University; Liu Jian(2010)[8] thought that local undergraduate institute can establishing the training system of comprehensive practical ability around the goal of talent training, by strengthening practice teaching, opening laboratory, strengthen the construction of the practice base outside school, developing cooperative education of industries-universities-research, cultivating the application ability of students; Luo qiushi(2010)[9] pointed out the suitable cooperated education model of industriesuniversities-research for local undergraduate institute: technical service, project research, relying on the base and independent business. And suggests that encourage the government and the enterprise to participate in the activation of cooperative education actively, encourage teachers to carry out cooperative education and establish the platform of industries-universities-research; Peng $\mathrm{Xu}(2010)[10]$ analysis the existing problems of industriesuniversities-research in our domestic situation for local applied undergraduate institute, and put forward the corresponding countermeasures; Dai Guozhong, Liu Aihua $(2011)^{[11]}$ talked about the industries-universitiesresearch success experience of Changzhou Institute, combined with the characteristics of local applied undergraduate institute, according to the development of civil engineering discipline construction and the social demand for talents, in-depth exploration in cooperative education, achieved good application effect.

Liu Guoyuan(2010)[12] thought that it should further change education ideas, deepen the reform of education and teaching, establish training objectives and practice of scientific talent, timely adjustment of professional structure, strengthen the close contact with the local government, society, enterprise, the industries-universities-research is effective in promoting common development of local applied undergraduate institute and local economic construction.

\section{B. Collaborative Innovation Research of Government- Industries-Universities-Research}

Huang Limin, Chen Zhi(2011)[13] at home and abroad on the subject clusters, industry clusters and collaborative innovation based on the relevant research results. Discussed the necessity and research contents of collaborative innovation to strengthen the subjects cluster and industries cluster in Hubei province, the main contents of the study include: exploring the development rules, the internal relations and seek the development trend, analysis its matching degree, formation cause and collaborative innovation of development, puts forward the collaborative innovation developing model of the subjects cluster and industries cluster as the guide, and create characteristic industry policy system of developing the subjects cluster and industries cluster; Chen Baoming(2009)[14] thought that we had a lot of problems on industries-universitiesresearch: facing all power and ability to butt, lack of longterm mechanism, industrial chain collaborative innovation is not enough, personnel communication disorder and the policy environment is not perfect and etc.. So we need to strengthen implementing the coordination mechanism and policies on industries-universities-research, organization configuration innovation of government science and technology resources, complete the industrial innovation chain, and explore the part-time professor system and etc..

Shan Baole, Yuan Yijun(2011)[15] constructed the evolution equation of technology alliance innovation system on industries-universities-research based on the collaborative theory related methods. After analysis, gave out the different organizing model of technology alliance on industries-universities-research, and thought that the main transform technological alliance on industries-universitiesresearch is a key element in the changing organizing model, in the necessary time the government should play a key role to participate; Wang Fuyu, Li Jingde(2008)[16] thought that the new mechanism and the new mode of collaborative innovation system on industries-universities-research is the inevitable developing trend of the subjects and industries cluster in the era of knowledge economy, it's the basic means to conquer complexity problem in science and technology innovation, it's the inner requirement to promote national and regional independent innovation ability and the core competitive power rapidly, it's an important way to construct the national innovation system; Jiang Yuxi, Hu Xiaoqing(2011)[17] thought that industries-universitiesresearch can complete collaborative innovation With the aid of university science park providing information and the platform of resources communication and integrated services and collaborative management mechanism; He Yubing $(2012)^{[18]}$ proposed a three interactive collaborative innovation mode on industries-universitiesresearch :"strategy_-knowledge — organization", exploring the construction of the preliminary collaborative innovation theory framework on industries-universities-research.

The analysis of the existing literature, mainly in industries-universities-research and collaborative innovation 
of domestic and foreign scholars, carried out extensive and in-depth research, and achieved a good result, it had a guiding role in very large in practice. Review of the literature in talent cultivating, we found that there are a lot of mining prospect to the original study. We think it can be used as a research direction: how to blend into the combination of the role of government common in collaborative innovation, government plays a greater role in industries-universities-research. It's a developing tendency and a kind of progress for the local applied undergraduate institute from the perspective of talent cultivation.

\section{THE PROBLEM IS PUT FORWARD}

The collaborative innovation theory was studied mainly at the micro, focusing on their respective cooperation between government, universities, research institutes and enterprises. At the same time, there are some problems on Independent innovation in China: lack of enterprise core technology ability, innovation power is not enough, science and technology achievements conversion rate of the local applied undergraduate institute and research institute is lower, all of those restrict economic boom.

The research and practice mainly concentrated in the enterprise- university cooperation, the governmentuniversities cooperation, the government- scientific research institutions cooperation, the universities-scientific research institutions cooperation. The above cooperation promotes the development of scientific research, but the lack of scientific research cooperation in depth, innovation is also reflected.

How to solve the problem, need to be studied further, we need to construct the collaborative innovation system of government-industries-universities-research to promote efficient transformation, to promote scientific research for local industry innovation needs, to create a technology and industry with the situation. Base on the above, we'll study the collaborative innovation of government-industriesuniversities-research, and further study its mechanism, then put forward some suggestions.

\section{RESEARCH ON THE COLLABORATIVE INNOVATION MECHANISM OF TALENTS TRAINING FOR THE LOCAL APPLIED UNDERGRADUATE INSTITUTE}

\section{A. Research on the Innovation Mechanism Based on the Interactive Interests}

1) Benefits associated between the local applied undergraduate institutes and enterprises: Serving for the local economy, benefits associated between the local applied undergraduate institutes and enterprise is mainly reflected in three aspects: firstly, it provides scientific and technical service for the enterprises, the second is to delivery qualified talents for enterprises, and the third is to provide training services platform for the enterprises. It's the key to survive for the local applied undergraduate institutes to cater to the demand of the enterprises, and realize the win-win situation. It's the common point to solve the issues of enterprise technology and management. The scientific research team of the local applied undergraduate institutes can satisfy the development and management needs of the enterprises. Enterprise's scientific research funds support can provide a good platform for developing the local applied undergraduate institutes and its scientific research teams.

2) Benefits associated between the local applied undergraduate institutes and government: The local government can affect the development of the local applied undergraduate institute to achieve the social public goal about ideological education and education fairness and education quality and serve the society economy and etc.. The local applied undergraduate institutes reserve a large number high level talent about scientific and technological research and development and management theory. Longer school histories of the local applied undergraduate institutes have accumulated many experiences for serving social and local economic. So the government and the local applied undergraduate institute have the common interests goal, both collaborative innovation can create a good development situation for social and economic industry.

3) The local applied undergraduate institutes and alumni interaction: The local applied undergraduate institutes have trained many alumni, they distributed in different area, different industry, engaged in different professions, their work performances show personal qualities, but also to propaganda the alma mater to the society widely. In society, let more and more people pay attention to the alma mater, to understand and know our scientific research strength, cultivating ability, the ability of social services. Some successful alumni thanked the alma mater through participating in school construction, some provide good practice platform and employment platform and resource information platform and etc.. It further promotes the development of the school. At the same time, by building trust and mutual benefit and stable cooperative relations with alumni, it is conducive to the cultivation of high-quality talents and scientific research achievements in the local applied undergraduate institutes, to realize a win-win situation for the local applied undergraduate institutes and the alumni, enterprise, research institutions and government.

\section{B. Knowledge Value-Added Analysis}

Collaborative innovation take knowledge value as the core status, it's a knowledge value added creation process to take the enterprise and university and scientific research institutions and government and science technology intermediary as the main innovation body (see Figure 1). At the era of knowledge economy, traditional factors drop, information and knowledge is increasing becoming the main wealth creators. Knowledge of the mining and development, sharing and diffusion, feedback and extraction, the cycle of life, and then transformed into human capital, the local applied undergraduate institutes can cultivate more knowledge talents, get scale effect and scope effect, service 
to the society and economy.

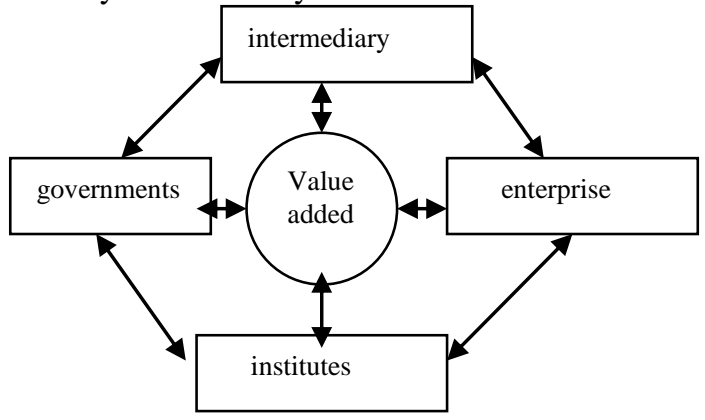

Figure 1. An knowledge value added creation process

\section{The Market Demand of Traction and the Scientific Research Achievements Attraction}

The market demands provide the impetus to the development of the local industrial cluster. The industrial cluster innovation meet the development of demand pull, technology innovation, cost control, product quality and productivity, it's a positive response to market demand traction. The development of industrial clusters requires much more technical and management personnel, so as to promote the development of discipline cluster for the local applied undergraduate institutes. The development of discipline clusters requires a cooperation way of government-industries-universities-research, to cultivate the talents for industry development. The market demand take the industry, government, the local applied undergraduate institutes as a link, and promote mutual assistance and cooperation of the three.

The collaborative innovation of government-industriesuniversities-research can develop innovative process and product technology in the original basis. And through the diffusion of technology, it can be applied to other industry, so you can change the industrial technical features and product features, develop a new product market. The local applied undergraduate institutes, as the main holder and provider of scientific and technological achievements, we should transform the original development mode, develop the basic research results into the industrial application achievements. Industry can gain lasting use by reasonable transferred pricing. At the same time, we can cultivate talents in collaborative research and developing process.

In addition, the government provides appropriate cooperation environment for collaborative innovation, the use of policy guidance, and control of the investment direction of research and developing, promote the collaborative innovation process, that's named the government planning.

Of course, the benefits temptation is a very important reason. The collaborative innovation should realize a winwin in government-industries-universities-research. Behind in the win-win, we can promote many in the investment and policy and research and development and the personnel training to explore a relatively low cost and high efficiency mode based on their own interests and established cooperation target so as to maximize the benefits of the parties. The benefit is the material guarantee in lasting collaborative innovation.

\section{RESEARCH ON THE PERSONNEL TRAINING COLLABORATIVE INNOVATION MODE OF THE LOCAL APPLIED UNDERGRADUATE INSTITUTES}

\section{A. Design the Government-Industries-Universities- Research Collaborative Innovation Platform}

The collaborative innovation body is governmentindustries-universities-research. The specific platform model designs include:

1) Take the company as the main, the local applied undergraduate institutes participate in the platform:The national center of silicon steel research platform is established by joint declaration of Wuhan Iron and Steel Group Corp and Wuhan University of Science and Technology.

2) Take the local applied undergraduate institutes as the main, the platform cooperation build by institutes and enterprises:This research institute of iron and steel platform is cooperation established by Wuhan Iron and Steel Group Corp and Wuhan University of Science and Technology.

3) Take the government as the main, the institutes and enterprises joint participation in the platform.:Guangdong science and technology consultant joint technology research and development platform, the local government is the leading.

4) Take the enterprises as the main, the cooperation platform by institutes and enterprises: Such as the joint technical innovation platform, it takes the technical innovation as the main body.

5) The talents cultivation platform, cooperation between institutes-enterprises:The enterprises and the local government cultivate talents with common cooperation.

\section{B. Construct the Government-Industries-Universities- \\ Research Model Based on the Industrial Cluster and Subject Cluster}

Construction of industrial technology innovation strategy alliance (see Figure 2), it is with the market oriented, enterprises cluster as the main body, the collaboration of the local applied undergraduate institutes and the scientific research Institutes to build the strategic alliances. They develop scientific research cooperation around industrial technology innovation, integration of the advantages of the industrial cluster and the discipline cluster. This can cultivate more comprehensive innovation talents. 


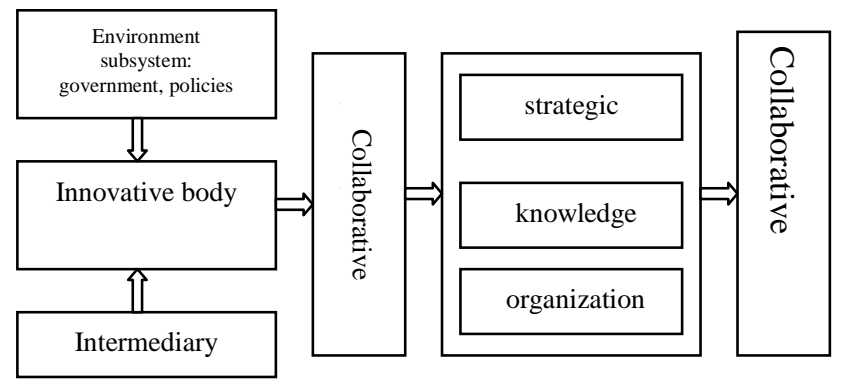

Figure 2. The collaborative innovation mode industrial cluster and discipline cluster

\section{The Government-Industries-Universities-Research Collaborative Innovation Model Based on the Technology Alliance}

In order to obtain the collaborative innovation economic and social effects and realize national innovation strategy, the sincere cooperation of government-industriesuniversities-research, we establish the government-led technology alliance collaborative innovation mode (see Figure 3). The government plays a policy guidance role in the technology alliance, promotes the cooperation of government-industries-universities-research, establish a long-term cooperative partnership. The innovation talents of technology and management are cultivated more quickly. The result is: transformation of scientific and technological achievement, personnel training better service high-tech park and key science and technology plan because of government-industries-universities-research.

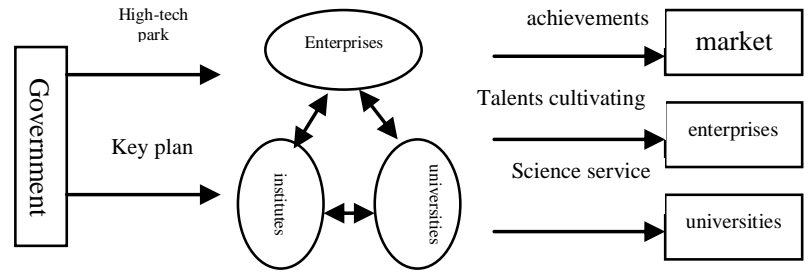

Figure 3. The collaborative innovation government-led technology alliance model

\section{POLICIES RECOMMENDATIONS}

\section{A. System Security}

At present the development needs, we should set up corresponding systems. The systems mainly reflect in: first, to establish and perfect the modern university system, clarify the interests of the local applied undergraduate institutes. Second, establish and perfect the system of independent flow, scientific research personnel exchanges and selection. Third, perfect the mechanism of financial support and policy guidance in government-industriesuniversities-research to establish the good collaborative innovation platform. Fourth, establish collaborative innovation benefit sharing system related.

\section{B. Establish An Ideas of Demand-Oriented and Cooperation And Science}

The collaborative innovation needs good idea guidance. The market demand-oriented idea and mutual cooperation concept and scientific concept are the most prominent. The market demand idea is to rely on technology and management problems of social and economic, by market demand guide, in the process of service social and service economy, to enhance the technology and scientific research innovation ability for the local applied undergraduate institutes. The cooperation concept is a new idea in government-industries-universities-research, to break up carrying out the activities alone, to focus on various advantages, to play director, to get efficient innovation and cost saving, it plays team strength, to achieve innovation. Another big scientific concept is: the technology trend integration of domestic and international, now and future, making scientific research into the local applied undergraduate institutes, making the science technology achievements into the enterprises and the government, the science and technology innovation has become the new driving force of developing the local applied undergraduate institutes. So we can facilitate the collaborative innovation in government-industries-universities-research to carry out smoothly.

\section{Collaborative Innovation Measures Implementation}

We should promote the reform of scientific research system for the local applied undergraduate institutes, accept the collaborative scientific research achievements, encourage joint horizontal and vertical development. We should reform the personnel training system of the local applied undergraduate institutes, build scientific research activity system attracting students joining into, get a good situation of teachers and students for cooperation research. We should unify planning science and technology management system, personnel system, education system and etc., for different policy, but for the realization of collaborative innovation, to remove obstacles. the internal and external collaborative innovation can be lasting to prompt government-industries-universities-research.

\section{ACKNOWLEDGMENT}

This research was financially supported by the Hunan Province Ordinary High School Teaching Reform Research Subject of China (Grant NO. 2010-323) and the Applied Economic Teaching Team Construction Project for Hunan Institute of Engineering (Grant NO.hnie2011-03).

\section{REFERENCES}

[1] Nelson, Richard R. and Sidney G.Winter, An evolutionary theory of economic change. Belknap Press of Harvard University Press, pp.125-150, 1982 .

[2] Dosi, Giovanni, Chirstopher Freeman, Richard Nelson, Gerald Silverberg, and Lue Soete(eds.). Technical change and economic theory, Pinter Pub Ltd ., pp. 220-265, 1988.

[3] Leydesdorff, Loet. "New Models of Technological Change : New Theories for Technology Studies?" Evolutionary Economics and 
Chaos Theory: New Directions in Technology Studies, Loet Leydesdorff \& Peter van den Besselaar (eds.). London: Pinter, pp. 180-192, 1994.

[4] Christopher Freeman.Technology policy and economic performance: Lessons from Japan. London: Pinter Publishers, pp.80-120, 1987.

[5] Nelson, Richard R.Edit..National Innovation Systems: A Comparative Analysis, Oxford University Press: New York,pp.300-356, 1993.

[6] Liu Yunfei , Wu Xuesong, The cooperative education and cultivating the applied talents in industrial-universities-research: based on the perspective of the local applied undergraduate institutes, Journal of Jinling Institute of Technology (Social Science Edition), China, vol. 22,No.3, pp.73-77, 2008.

[7] Zhou Huali, Xiao Zhangke, Luo Xiao, Explore and practice cooperative education model of the local college: To Beijing Union University as an example, Journal of Beijing Education, China, vol. 546,No.10, pp. 68-70,2010.

[8] Liu Jian, Analysis on innovative applied talents comprehensive training system, Journal of Dongguan University of Technology, vol. 17,No.4 , pp. 108-204, 2010.

[9] Luo Qiushi ,Cooperative education mode innovation and practice of newly established local colleges and universities :To Hunan University of Humanities Science and Technology as an example, Journal of Hunan University of Humanities Science and Technology, China, vol. 117,No.6, pp. 80-84, 2010.

[10] Peng $\mathrm{Xu}$, The industries-universities-research model analysis under the perspective of training applied talents for the local undergraduate colleges and universities, Journal of Science and Technology Management Research, China, vol. 30,No.215 , pp. 143-145, 2010.

[11] Dai Guozhong, Liu Aihua, Research and practice of industriesuniversities-research cooperative education based on the innovative talents cultivation, Journal of Changchun University of Science \& Technology,China, vol. 24,No.3, pp. 117-119, 2011.

[12] Liu Guoyuan, To strengthen thinking about the cooperative education for local universities and colleges of industries-universities-research, Journal of Huizhou College (Social Science Edition),China , vol. 30,No.5, pp. 114-117, 2010.

[13] Huang Limin , Chenzhi, The discussion of collaborative innovation research content of the industrial cluster and the discipline cluster Journal of Science and Technology Management Research,China, vol. 31,No.1, pp. 184-187, 2011.

[14] Chen Baoming, Some problems and the policy suggestion of cooperation on industries-universities-research in China, Journal of University Science and Technology and Industrialization ,China, vol. 255,No.11, pp. 42-45, 2009.

[15] Shan baoyue, Yuan Yijun, Technology alliance form model research on industries-universities-research under the perspective of the evolution, Journal of Technology and Management, vol. 13,No.5, pp. 29-34, 2011

[16] Wang Fuyu, Li Jingde, Industry cluster call discipline cluster: Talk about the collaborative innovation of industries-universities-research, Journal of China's Science and Technology Industry ,China, vol. 252,No.6, pp. 61-65, 2008

[17] Jiang Yuxi, Hu Xiaoqing, The function and benefit analysis of government-industries- universities-research of collaborative innovation in University science park, Journal of Modern Education Management,China, vol. 257,No.8, pp. 33-36, 2011

[18] He Yubin, The theory model of the collaborative innovation in industries-universities-research, Journal of Studing Science of Sciences ,China, vol. 30,No.2, pp. 165-174, 2012 